\title{
Contents to Volume 12 (2016)
}

\section{Editorial 1}

Abbreviations 2

Ethiopians and the Others: Cultures of the Christian Orient in the Middle Ages

Serge Frantsouzoff and Basil Lourié

"Angels in the Guise of Saints": A Syrian Tradition in Constantinople $\quad 5^{-19}$ Vladimir Baranov

On the Dating of the Ethiopian Dynastic Treatise Kəbrä nägäśt:

New Evidence 20-24

Serge A. Frantsouzoff

Joasaph II in an Unpublished List of the Metropolitans of the Ethiopian

Church 25-34

Ekaterina V. Gusarova

The Disputed Life of the Saintly Ethiopian Kings 'Abrəhā and

'Aṣbə⿳亠丷冖 $\quad 35^{-72}$

Susanne Hummel

An Archaic Jewish-Christian Liturgical Calendar in Abba Giyorgis of

Sägla $\quad 73-83$

\section{Basil Lourié}

The Old Chants for St. Gärima: New Evidence from Gär'salta 84-103 Denis Nosnitsiwn

The Epistles of Niketas Stethatos: The Data of the Georgian

Version 104-125 Alexey Ostrovsky and Maia Raphava

The Newly Discovered Treatise on Patriarch Nikon in the Cultural and Historical Context of Its Epoch 126-180

Svetlana K. Sevastyanova 


\section{ARTICLES}

Understanding Origen: The Genre(s) of the Gospels in Light of Ancient Greek Philology and Modern Genre Theory 181-214

CarlJohan Berglund

The Principle of Individuation in Contra Eunomium 2, 4 by Basil of Caesarea and Its Philosophical and Theological Context $\quad 215^{-243}$

Dmitry Biriukov

A Brief History of Self-Reference Notion Implementation in

Byzantium 244-260

Oksana Yu. Goncharko and Yury M. Romanenko

Between Tritheism and Sabellianism $\quad 261-280$

Dirk Krausmuller

Gregory of Nyssa's Life of Gregory Thaumaturgus and the Conversion of Neocaesarea $281-290$

Byron MacDougall

Theology for Rent: Nicholas Mesarites as a Compiler of Andronicus

Camaterus $\quad 291-307$

Dmitry I. Makarov

Identity in Difference: Substance and Nature in Leontius of Byzantium's

Writings $\quad 308-321$

Timur Shchukin

Sur l'origine des sobriquets de Jean le Grammairien «Jannes" et

"Sorcier» $322-328$

Tatiana A. Sénina (nonne Kassia)

\section{REVIEW ARTICLES}

Caught in Transition: Liturgical Studies, Grand Narratives, and Methodologies of the Past and the Future $\quad 329-339$

\section{Arkady Avdokhin}

Temporality and a Metric for Created Natures in Gregory of Nyssa $\quad 340-35^{2}$ Basil Lourié

NOTES

The Cosmology of John Damascene and Its Antique Context 353 Dmitry Biriukov 
Notule sur une mystérieuse église byzantine de Kaouvi: Le colophon géorgien du manuscrit 'Iviron géorg. 69' 361

Sergey Kim

The Most Ancient Greek Manuscripts of the Ladder of John Climacus 368

Tatiana G. Popova

Some Notes on the Life and Works of Maxim the Greek (Michael Trivolis, ca 1470 - Maksim Grek, 1555/1556): Part 2: Maxim the Greek's Slavic Idiolect 375

Neža Zajc

BOOK REVIEWS

Tatiana Senina (nun Kassia) (ed.): Св. Кассия Константинопольская, Гимны, каноны, эпиграммы, Кассия Константинопольская: жизнь и творчество $383-387$

Basil Lourié

Erica A. Mathieson: Christian women in the Greek papyri of Egypt to 400 CE $388-390$ Elena Chepel

Isaac W. Oliver: Torah Praxis after 70 CE. Reading Matthew and Luke-Acts as Jewish Texts $\quad 391-394$

Basil Lourié

Nino Sakvarelidze: Liturgie als Symbol und Mysterium. Die Himmelsliturgie des Dionysius Areopagites und ihre altgeorgische Rezeption $\quad 395^{-397}$ Basil Lourié 